\title{
TEKNIS PEMELIHARAAN IKAN LELE PADA KOLAM HEMAT AIR DAN EFISIEN PAKAN DI DESA LUMBUNG KECAMATAN SELEMADEG BARAT KABUPATEN TABANAN
}

\author{
I.N. Ardika ${ }^{1}$, N.W. Suniti ${ }^{2}$, I.M. Mega ${ }^{3}$ dan N.N. Yastini ${ }^{4}$
}

\begin{abstract}
ABSTRAK
Program Kemitraan Wilayah (PKW) Desa Lumbung Kecamatan Selemadeg Barat Kabupaten Tabanan bertujuan untuk menberdayakan kelompok pemelihara ikan lele dalam pemeliharaan ikan lele dengan menggunakan kolam hemat air dan efisien pakan. Metode yang diterapkan dalam pemberdayaan masyarakat pada kegiatan ini meliputi: (1) Koordinasi dan komunikasi secara partisipasif dengan kelompok pemelihara ikan lele untuk merumuskan program mulai dari perencanaan, operasional dan evaluasi; (2) Penyuluhan untuk membangun persepsi dan pemahaman kelompok mengenai inovasi program yang diterapkan; (3) Pelatihan mengenai terapan teknologi yang diaplikasi bagi masyarakat; (4) Pendampingan yaitu pertemuan secara berkala dan berkelanjutan antara pendamping dengan kelompok sasaran hingga teknologi yang diaplikasikankan dapat dilaksanakan secara tepat. Pemeliharaan ikan lele pada kolam hemat air dan efisien pakan meliputi: persiapan pembuatan kolam dari terpal, pengaturan air, penebaran benih, pakan, pencegahan terhadap penyakit dan panen. Hasil pengabdian menunjukkan bahwa pemeliharan ikan lele pada kolam hemat air dan efisien pakan telah berjalan dengan baik. Hal ini ditunjukkan dengan hasil panen ikan lele pada pemanenan pertama sebanyak $222 \mathrm{~kg}$, panen kedua sebanyak $135 \mathrm{~kg}$ dan panen ketiga sebanyak $75 \mathrm{~kg}$ dengan ukuran 6-7 ekor/kg.
\end{abstract}

Kata kunci : ikan lele, kolam hemat air, efisien pakan

\begin{abstract}
The Regional Partnership Program (PKW) of Lumbung village, West Selemadeg sub-district, Tabanan regency, aims to empower catfish keeper groups in raising catfish by using water-saving ponds and efficient feed. The methods applied in community empowerment in this activity include: (1) Participatory coordination and communication with catfish keeper groups to formulate programs ranging from planning, operating and evaluating; (2) Counseling to build group perceptions and understanding of the innovations of the implemented program; (3) Training on applied technology that is applied to the community; (4) Assistance is a regular and ongoing meeting between the facilitator and the target group until the applied science and technology can be implemented appropriately. Maintenance of catfish in water-saving ponds and efficient feed includes: preparation of making ponds from tarpaulins, water management, stocking of seeds, feed, prevention of disease and harvest. The results of dedication show that raising catfish in a water-efficient and efficient feed pond has been going well. This is indicated by the yield of catfish in the first harvest of 222 $\mathrm{kg}$, the second harvest of $135 \mathrm{~kg}$ and the third harvest of $75 \mathrm{~kg}$ with a size of 6-7/kg.
\end{abstract}

Keywords: catfish, water-saving pond, efficient feed

\footnotetext{
${ }^{1}$ Fakultas Peternakan Universitas Udayana, ardika@ unud.ac.id.

${ }^{2}$ Program Studi Agroekoteknologi Fakultas Pertanian Universitas Udayana, sunitiwayan@gmail.com

${ }_{3}^{3}$ Program Studi Agroekoteknologi Fakultas Pertanian Universitas Udayana, mega made@yahoo.com

${ }^{4}$ Program Studi Pertanian Fakultas Pertanian Universitas Dwijendra, nengahyastini@gmail.com
} 


\section{PENDAHULUAN}

Desa Lumbung merupakan salah satu desa dari 5 desa yang menjadi Kawasan Pembangunan Prioritas Nasional (KPPN) di Kabupaten Tabanan yakni 3 Desa di Kecamatan Pupuan, yaitu Desa Belimbing, Sanda dan Munduktemu, serta 2 Desa di Selemadeg Barat, yakni Desa Wanagiri dan Desa Lumbung Kauh. Pengembangan KPPN di Kabupaten Tabanan di arahkan kepada integrasi antara pertanian dengan pariwisata, yaitu melalui pengembangan desa wisata berbasis komoditas pertanian. Dalam pengembangan desa wisata, perlu dikembangkan atraksi wisata yang spesifik dan autentik/asli wilayah desa yang bersangkutan (Sardiana and Purnawan, 2017). Masyarakat lokal diharapkan menjadi pelaku utama dalam pengelolaan desa wisata, mulai dari perencanaan, pelaksanaan hingga evaluasi (sardiana and Purnawan, 2016; Purnawan and Sardiana, 2015).

Luas wilayah mencapai $12,70 \mathrm{~km}^{2}$. Jarak dari kota Denpasar sekitar $42 \mathrm{~km}$, sedangkan jarak dari kota Tabanan sekitar $20 \mathrm{~km}$. Desa Lumbung penggunaan lahan di wilayah ini utamanya untuk lahan tegalan/kebun 1266,692 ha (71,96\%), diikuti lahan sawah 422,232 ha (23,99\%), pekarangan 51,8 ha $(2,94 \%)$, dan lain-lain 19,66 ha $(1,12 \%)$.

Jumlah penduduk untuk Desa Lumbung sebanyak 3515 dengan komposisi 2249 laki-laki dan 2359 perempuan yang terbagi dalam $1257 \mathrm{KK}$. Penggunaan lahan di wilayah ini utamanya untuk lahan tegalan/kebun 1266,692 ha (71,96\%), diikuti lahan sawah 422,232 ha (23,99\%), pekarangan 51,8 ha $(2,94 \%)$, dan lain-lain 19,66 ha $(1,12 \%)$. Struktur penduduk menurut mata pencaharian menunjukkan bahwa sebagian besar penduduk menggantungkan sumber kehidupannya di sektor pertanian (82\%), diikuti sektor perdagangan (4.\%), sektor industri rumah tangga dan pengolahan $(2,3 \%)$, sektor jasa $(0,8 \%)$ dan sektor lainnya seperti pegawai negeri, karyawan swasta $(1,6 \%)$. Angka tersebut mengindikasikan bahwa sektor pertanian merupakan bidang startegis sehingga perlu mendapatkan prioritas.

Dalam Rencana Pembangunan Jangka Menengah (RPJM) Kabupaten Tabanan yang terkait dengan wilayah PKW meliputi tiga sektor yaitu: ekonomi, perikanan, dan pertanian. Sektor pertanian, khususnya subsektor perkebuanan wilayah PKW merupakan sentra produksi kelapa (Pemda Tabanan, 2016). Bidang ekonomi diarahkan untuk mengembangkan kelompok usaha bersama (KUBE) yang memproduksi produk olahan hasil pertanian dan BUMDES (badan usaha milik desa) yang selanjutnya bertugas membeli dan memasarkan produk KUBE. Sektor strategis yang lain adalah bidang perikanan yaitu pengembangan perikanan air tawar melalui perbaikan budidaya, pengadaan pakan, pengolahan dan pemasaran produksi perikanan.

Kondisi Desa Lumbung dengan sumber air yang cukup telah mendorong munculnya unit-unit usaha pengembangan ikan air tawar. Terdapat 3 kelompok unit usaha pengembangan ikan air tawar yang tersebar di 2 dusun. Jumlah petani yang menjadi anggota dari kelompok tersebut berjumlah 72 orang. Potensi perikanan yang demikian besar belum dikelola secara memadai. Jenis ikan yang banyak dibudidayakan diantaranya lele, nila dan gurami. Namun demikian, sejalan dengan menurunnya debit air, usaha budidaya ikan air tawar berkurang karena terkendala persaingan penggunaan air untuk pertanian sawah. Selain itu, mahalnya harga pakan juga menjadi pemicu menurunnya minat budidaya ikan air tawar di Desa Lumbung. Aplikasi teknologi budidaya ikan hemat air dan efesien pakan menjadi kebutuhan yang mendesak untuk menggairahkan kembali usaha budidaya ikan air tawar di desa ini. 


\section{METODE PELAKSANAAN}

\subsection{Metode}

Metode yang diterapkan dalam pemberdayaan kelompok pemelihara ikan lele pada kegiatan PKW ini adalah sebagai berikut: (1) Penyuluhan untuk membangun persepsi dan pemahaman anggota kelompok khususnya Kelompok Matsya Labda di desa Lumbung mengenai inovasi atau program pemeliharaan ikan lele yang diterapkan, (2) Pelatihan mengenai terapan ipeks pemeliharaan ikan lele yang diaplikasi bagi anggota Kelompok, dan (3) Pendampingan yaitu pertemuan secara berkala dan berkelanjutan antara pendamping dengan anggota Kelompok sasaran hingga ipteks pemeliharaan ikan lele yang diaplikasikan dapat dilaksanakan secara tepat oleh angota Kelompok.

\subsection{Pengumpulan data}

Pengumpulan data dilakukan dengan metode wawancara dengan anggota kelompok. Selanjutnya data pemeliharaan ikan lele pada kolam hemat air dan efisien pakan yang diperoleh dijabarkan secara deskripsi.

\section{HASIL DAN PEMBAHASAN}

Ikan lele adalah jenis ikan tawar yang sangat banyak diminati oleh masyarakat, harganya yang merakyat juga tekstur dan rasa yang gurih dan nikmat membuat ikan lele sangat familiar dan banyak digandrungi oleh semua kalangan masyarakat dari usia muda sampai yang tua. Saat ini banyak dijumpai rumah makan dan kios-kios pinggir jalan yang mengusung menu utama lele, masakannya bervariasi mulai dari pecel lele, lele goreng dan lain-lain. Permintaan masyarakat yang sangat tinggi inilah yang membuat pemasok lele menjadi kewalahan.

Ikan lele sanggup hidup dalam kepadatan tinggi. Ikan ini memiliki tingkat konversi pakan menjadi bobot tubuh yang baik. Dengan sifat seperti ini, pemeliharaan ikan lele akan sangat menguntungkan bila dilakukan secara intensif. Pemeliharaan atau pembesaran ikan lele bertujuan untuk menghasilkan ikan lele siap konsumsi.

Ada bererapa tahap pemeliharaan atau pembesaran ikan lele yang dilakukan oleh Kelompok Matsya Labda di Desa Lumbung Kecamatan Selemadeg Barat Kabupaten Tabanan yaitu:

\subsection{Pembuataan kolam}

Kolam yang digunakan adalah kolam berbentuk bulat terbuat dari terpal, berdiameter 3 meter dengan tinggi 1,5 meter sebanyak 5 buah. Kolam terpal tersebut dipilih karena dinilai praktis dan dapat menghemat tempat, mudah mengontrol kualitas dan kuantitas air, lebih mudah pengeringan dan pembersihan air, serta lebih mudah pada saat panen. Pada dasar kolam, dipasangi pipa yang berfungsi sebagai pengaturan tinggi air dan jalan keluar kotoran lele yang mengendap pada dasar kolam.

\subsection{Pengaturan air}

Pengaturan air berfungsi untuk menyeimbangkan keasaman kolam dan membantu memberantas mikroorganisme pathogen. Ketinggian air yang ideal untuk pembesaran ikan lele adalah 80-100 cm (Pak Tani Digital, 2019). Dua hari setelah kolam diisi air, ditambahkan garam kurang lebih 1,5 $\mathrm{kg}$ dan ditaburi daun papaya $0,5 \mathrm{~kg}$. Air kolam didiamkan kurang lebih selama 7 hari sampai air kolam berwarna kehijauan. Warna air yang terbaik bagi ikan lele berwarna hijau menunjukkan bahwa kualitas air yang baik untuk ikan lele. Lele tidak suka air jernih dan air akan berubah 
kemerahan ketika ikan sudah dewasa untuk siap panen. Pengontrolan air kolam dilakukan setiap dua hari sekali.

\subsection{Penebaran benih}

Benih ikan lele tidak bisa langsung dimasukkan dalam kolam, harus dilakukan penyesuaikan terlebih dahulu dengan air kolam. Jika langsung dimasukkan dalam kolam, benih lele bisa stress dan mati. Cara penebaran benih lele menurut Azzamy (2018) adalah dengan mengisi air kolam pada suatu wadah, masukkan benih lele kedalam wadah dan diamkan selama 30 menit supaya benih ikan lele dapat menyesuaikan terhadap air kolam dan untuk menghilangkan stress ikan setelah dipindahkan dari habitat penangkaran dan akan masuk ke habitat baru. Penebaran benih dilakukan dengan memasukkan wadah yang berisi benih ikan lele dengan perlahan-lahan agar benih lele keluar dengan sendirinya. Untuk ukuran kolam terpal dengan diameter 3 meter dapat ditebarkan benih lele sebanyak 3000 ekor.

\subsection{Pemberian pakan}

Pada pemeliharaan ikan khususnya ikan lele merupakan aspek terpenting sebagai sumber gizi agar ikan lele dapat hidup dan berkembang dengan baik. Azzamy (2018) menyatakan bahwa pakan yang baik mengandung nutrisi yang seimbang. Nutrisi yang dibuthkan ikan lele secara umum adalah protein minimal 30\%, lemak 4-6\%, karbohidrat_15-20\%, serta vitamin dan mineral yang seimbang. Pakan diberikan dua kali sehari dengan mencampurkan pakan konsentrat ditambahkan prebiotik, enzim@ dan air secukupnya. Kemudian didiamkan beberapa saat agar pakan pada saat ditebarkan mengambang. Kadang-kadang juga diberikan daun papaya, daun talas sebagai pakan tambahan.

Jenis dan jumlah pakan yang diberikan dalam pemeliharaan pembesaran ikan lele selama satu periode pemeliharaan tertera pada tabel 1. Dari tabel tersebut terlihat bahwa terdapat jumlah dan jenis pakan yang diberikan sesuai dengan pertumbuhan ikan dan total pakan yang diberikan adalah sebanyak 34 sak.

Tabel 1. Jumlah dan jenis pakan pada pemeliharaan/pembesaran ikan lele selama satu periode panen

\begin{tabular}{|l|l|c|}
\hline No & Jenis pakan lele & $\begin{array}{l}\text { Jumlah pakan } \\
\text { (sak) }\end{array}$ \\
\hline 1 & PF1000 & 1 \\
2 & Inova-1 & 2 \\
3 & Spala-12 & 7 \\
4 & Hi-Pro-Vite-2 & 1 \\
5 & Spala-12-2 & 1 \\
6 & LA7K-2 & 3 \\
7 & LA7K-3 & 8 \\
8 & LA7K-3 & 3 \\
9 & Hi-Pro-3 & 2 \\
10 & LA7K-2 & 9 \\
11 & LA7K-2 & 1 \\
\hline
\end{tabular}

\subsection{Pensortiran ikan lele}

Pensortiran ikan lele dimaksudkan untuk memisahkan lele berdasarkan ukurannya dan untuk mengurangi kanibalisme. Pensortiran ikan lele dilakukan lebih kurang pada umur 20 hari setelah penebaran benih, kemudian pisahkan ikan lele yang besar dan kecil dalam kolam yang berbeda. 
Pensortiran selanjutnya dilakukan pada saat lele dipanen. Pemisahan ukuran saat dipanen berdampak pada harga jual.

\subsection{Pencegahan penyakit}

Beberapa penyakit ikan lele pada kolam terpal yang sering ditemukan antara lain: penyakit kembung perut, luka di kepala dan ekor serta penyakit bintik putih. Penyakit tersebut disebabkan oleh mikroorganisme pathogen seperti bakteri dan protozoa. Cara pengendalian penyakit pada ikan lele di desa Lumbung dilakukan dengan menambahkan garam pada air kolam. Azzamy (2018) menyarankan cara pencegahan penyakit yang menyerang ikan lele pada kolam terpal yaitu dengan cara menjaga kualitas air agar tetap bersih dan sehat, memberikan pakan sesuai dengan kebutuhan serta mempertahankan suhu air kolam pada kisaran $28^{\circ} \mathrm{C}$.

\subsection{Panen ikan lele}

Ikan lele sudah bisa dipanen pada umur 2,5 bulan atau 3 bulan setelah tebar benih. Ukuran atau bobot ikan lele siap panen bervariasi tergantung pada permintaan pasar (Azzamy, 2018). Bila dijual ke rumah makan, warung pecel lele atau restoran dan hotel pada umumnya ikan lele dipanen jika bobot per ekor berkisan antara 80-125 gram atau sekitar 8-12 ekor per kilogram. Pada saat panen ikan lele disortir sesuai dengan ukurannya. Ikan lele yang lebih kecil, selanjutnya dipelihara kembali sampai ukuran yang sesuai dengan pasar. Panen ikan lele di Desa Lumbung Kecamatan Selemadeg Barat Kabupaten Tabanan dilakukan sebanyak tiga kali. Panen pertama diperoleh ikan lele sebanyak $222 \mathrm{~kg}$ dengan ukuran 6-7 ekor/kg. panen kedua diperoleh ikan lele sebanyak $135 \mathrm{~kg}$ dan panen ketiga kali diperoleh $75 \mathrm{~kg}$.

\section{KESIMPULAN DAN SARAN}

\subsection{Kesimpulan}

Dari uraian diatas dapat disimpulkan bahwa program pengabdian khususnya pemeliharan atau pebesaran ikan lele pada kolam hemat air dan efisien pakan telah berjalan dengan baik. Hal ini ditunjukkan dengan kelompok telah berhasil panen ikan lele sebanyak 432 kilogram dengan ukuran 6-7 ekor/kg sesuai dengan permintaan pasar.

\subsection{Saran}

Saran yang dapat diberikan kepada kelompok pemelihara ikan lele adalah untuk menambahkan sirkulasi air pada kolam terpal untuk menjaga kualitas air kolam.

\section{UCAPAN TERIMAKASIH}

Penulis menyampaikan terima kasih yang sebesar-besarnya kepada Direktorat Riset dan Pengabdian Kepada Masyarakat Direktorat Jenderal Penguatan dan Pengembangan Kementerian Riset, Teknologi dan Pendidikan Tinggi atas pembiayan yang diberikan untuk pelaksanaan Program kemitraan Wilayah di Desa Lumbung, Kecamatan Selemadeg Barat, Kabupaten Tabanan, Ketua Lembaga Pengabdian kepada Masyarakat Universitas Udayana, Bappeda Kabupaten Tabanan, serta seluruh masyarakat yang telah membantu kelancaran kegiatan ini.

\section{DAFTAR PUSTAKA}


Azzamy. 2018. Panduan praktis budidaya ikan lele di kolam terpal bagi Pemula, Mudah dan Murah.

Pemerintah Kabupaten Tabanan. 2016. RPJM Kabupaten Tabanan tahun 2016-2021 (Perda No.9/2016). Pemkab Tabanan.

Pak Tani Digital. 2019. Cara beternak ikan lele dengan system bioflok. Pasar Online dan Media Online Pertanian Indonesia.

Purnawan, NLR., I.K Sardiana. 2017. Paket Wisata Edukasi Subak Upaya Menjaga Keberlanjutan Potensi Pertanian dan Pariwisata Berbasis Budaya di Bali. Jurnal Kawistara 7 (3), 275-284

Sardiana, IK., NLR Purnawan., 2016. Indigenous community, ecotourism and sustainability: Experience from Tenganan Dauh Tukad traditional. Heritage, Culture and Society: Research agenda and best practices in the hospitality and tourism ind | vol: | issue : |2016-01-01 | Conference Proceedin

Sardiana, IK., NLR Purnawan. 2015. Community-based Ecotourism in Tenganan Dauh Tukad: An Indigenous Conservation Perspective. Jurnal Kajian Bali (Journal of Bali Studies) 5 (2), 347-368 